УДК 331.5:332.12

DOI: $10.25140 / 2411-5215-2020-3(23)-41-47$

Жанна Дерій

\title{
МІСЦЕ ЛЮДСЬКОГО КАПІТАЛУ В СИСТЕМІ МОДЕРНІЗАЦІЙНИХ ЗРУШЕНЬ РЕГІОНАЛЬНОЇ ЕКОНОМІКИ
}

\author{
Жанна Дерей \\ МЕСТО ЧЕЛОВЕЧЕСКОГО КАПИТАЛА В СИСТЕМЕ \\ МОДЕРНИЗАЦИОННЫХ ИЗМЕНЕНИЙ РЕГИОНАЛЬНОЙ ЭКОНОМИКИ
}

\author{
Zhanna Derii

\section{THE PLACE OF HUMAN CAPITAL IN THE MODERNIZATION SYSTEM} \\ OF THE SHIFTS OF THE REGIONAL ECONOMY
}

Модернізація регіональної економіки як явище являє собою складний процес прогресивних економічних, екологічних, політичних, сочіальних змін, які відбуваються в контексті четвертої промислової революиії, та має за мету перехід до високорозвинутого сталого суспільства з високим рівнем якості життя населення. 3 процесами модернізаиії суспільства пов'язують людський капітал, його нарощування та кардинально нову роль. Доктрина, яку покладено в основу модернізачії, свідчить, що ией прочес безпосередньо відбувається завдяки накопиченому людському капіталу. Інтеграція та розвиток технологій, які є необхідною компонентою модернізаційних зрушень, вимагає трансформації знань, нових компетентностей праиівника. Порядок денний майбутнього підкреслює важливість людської взаємодії в постмодерній економіці через функиії у сфері маркетингу та продажів, створенні та наповненні інформаційного контенту, роботі з різними типами особистостей та з різним рівнем кваліфікаиії. Наслідком модернізаційних змін є формування людського капіталу нової якості. Нарощений людський капітал та його реалізаиія дають змогу людській особистості бути одночасно кінцевим результатом економічного розвитку, елементом иъього процесу $і$ засобом подальшого розвитку. Тобто людський капітал отримує риси, які характеризують його як нову сочіальну категорію та одночасно виступає як вагомий чинник процесу і як об'єкт, на який направлено зміни.

Ключові слова: модернізація; регіональна економіка; людський потенціал; людський капітал; ефективність.

Рис.: 1. Бібл.: 9.

Модернизация региональной экономики как явление, представляет собой сложный процесс прогрессивных экономических, экологических, политических, сочиальных изменений, которые происходят в контексте четвертой промыпиенной революции, их иель - переход к высокоразвитому, устойчивому обществу с высоким уровнем качества жизни населения. Также с процессами модернизачии общества связывают человеческий капитал, его наращивание и кардинально новую роль. Доктрина, которая положена в основу модернизации, свидетельствует, что этот процесс непосредственно происходит благодаря накопленному человеческому капиталу. Интеграция и развитие технологий, которые являются необходимым компонентом модернизационных сдвигов, требуют трансформации знаний, новых компетениий работника. Повестка дня будущеего подчеркивает важность человеческого взаимодействия в постмодернистской экономике через функиии в сфере маркетинга и продаж, создании и наполнении информационного контента, работе с различными типами личностей и с разным уровнем квалификации. Следствием модернизационных изменений является формирование человеческого капитала нового качества. Накопленный человеческий капитал и его реализация позволяют человеческой личности быть одновременно конечным результатом экономического развития, элементом этого прочесса и средством дальнейшего развития. То есть человеческий капитал приобретает черты, характеризующие его как новую сочиальную категорию и одновременно выступать важным фактором процесса и как объект, на который направлены изменения.

Ключевые слова: модернизачия; региональная экономика; человеческий потенциал; человеческий капитал; эффективность.

Рис.: 1. Библ.: 9.

Modernization of the regional economy as a phenomenon is a complex process of progressive economic, environmental, political, social changes that occur in the context of the fourth industrial revolution, and aims to move to a highly developed sustainable society with a high quality of life. Human capital, its growth and a radically new role are associated with the processes of the society's modernization. The doctrine underlying modernization shows that this process is directly due to the accumulated human capital. Integration and development of technologies, which are a necessary component of modernization, requires the transformation of knowledge, new competencies of the employee. The agenda of the future emphasizes the importance of human interaction in the post-modern economy through functions in the field of marketing and sales, creation and filling up the information content, work with different types of individuals and with different levels of qualification. The consequence of modernization changes is the formation of human capital of a new quality. Increased human capital and its realization allow the human person to be both the end result of economic development, an element of this process and a means of further development. That is, human capital acquires features that characterize it as a new social category and at the same time acts as an important factor in the process and as an object to which change is directed.

Keywords: modernization; regional economy; human potential; human capital; efficiency.

Fig.: 1. References: 9.

JEL Classification: J24; R58

(c) Дерій Ж. В., 2020 
Постановка проблеми. Тема модернізації регіональних економік, чинників та факторів, що їі визначають, наслідків для територіальних економічних систем, стала актуальною та популярною в межах індустріального напряку сучасної футурології.

Соціально-економічні програми та заходи, технологічні інновації, структурна модернізація безпосередньо впливають на рівень конкурентоспроможності та сталості регіональних економічних систем, а зрушення проходять з урахуванням об'єктивних чинників цивілізаційного поступу та орієнтуються на природні, історичні, географічні, демографічні, економічні, екологічні особливості конкретної території.

Модернізація регіональної економіки як явище являє собою складний процес прогресивних економічних, екологічних, політичних, соціальних змін, які відбуваються у контексті четвертої промислової революції, та має за мету перехід до високорозвинутого сталого суспільства 3 високим рівнем якості життя населення. Також 3 процесами модернізації суспільства пов'язують людський капітал, його нарощування та кардинально нову роль. Саме регіони стають ландшафтом модернізаційних змін, регіональні особливості впливають на еволюційні зміни у структурі економіки та окремих ії елементів, зокрема людського капіталу.

Формування доктрини, яку покладено в основу модернізації, безпосередньо відбувається завдяки накопиченому людському капіталу, тому актуалізується питання визначення його місця та ролі в модернізаційних зрушеннях регіональних економік.

Аналіз останніх досліджень і публікацій. Останнім часом з'явилась велика кількість робіт із дослідження модернізації економіки та місця людини в цих процесах 3 урахуванням викликів та вимог сучасного поступу.

Зокрема ця проблема розглядається в працях науковців як української школи економічної думки, так і у працях закордонних фахівців. Проблемам модернізації економіки України в умовах глобалізації присвячено праці І. Бураковського, М. Бутка [1], А. Гречко, Б. Дергалюка, Е. Лібанової, Д. Лук’яненка, О. Мініної [6; 7], Ю. Пахомова, О. Попело, Р. Тульчинського, С. Тульчинської, В. Чужикова, Н. Шадури-Никипорець [7] та ін. Наукові пошуки стосуються як теоретико-методологічної бази модернізації, так i вивчення окремих компонент цього процесу, зокрема дослідження можливостей людського капіталу та його місця у процесах еволюції соціально-економічних систем.

Так, Е. Лібанова визначає, що складовими модернізації економіки є обгрунтована макроекономічна політика, макроекономічна стабільність і економічне зростання. Але їх у жодному випадку не можна трактувати як завдання модернізації - кінцевою метою $€$ забезпечення економічних можливостей розвитку людського потенціалу [5].

Б. Дергалюк досліджує питання структурної модернізації регіональної економіки через призму активізації інтелектуального потенціалу та врахування властивостей i специфіки конкретного регіону [3].

У працях Р. Тульчинського дано тлумачення категорії модернізації, під якою автор розуміє не тільки інноваційно-технологічне оновлення засобів виробництва, а й цивілізаційно-суспільний, революційно-проогресивний та незворотний процес, який включає розроблення та запровадження нових підходів до розвитку суспільних систем та нових методів соціально-економічного регулювання на регіональному рівні [8].

Виділення недосліджених частин загальної проблеми. Попри численні дослідження у цій сфері, актуальними залишаються питання місця та ролі людського капіталу в цих процесах, визначення суб'єктно-об'єктного складу відносин у сфері капіталізації людського потенціалу, викликаного модернізацією регіональних економічних систем.

Мета статті. Головною метою роботи є визначення ролі людського капіталу у процесах модернізації та роль для суспільного розвитку. 
ПРОБЛЕМИ МЕНЕДЖМЕНТУ ТА РОЗВИТКУ ПРОДУКТИВНИХ СИЛ РЕГІОНУ

Виклад основного матеріалу. Світ XXI ст. входить у четверту промислову революцію, яка докорінно змінює всі сфери суспільства - політичну, економічну, соціальну, екологічну, а пандемія, викликана COVID-19, ще більше вплинула на поєднання реально з віртуальним, зокрема в бізнесі, освіті, комунікації людей.

Регіональні господарські системи, як утворення, що постійно розвиваються та переходять на якісно нові рівні, стикаються з флуктаціями (коливаннями та відхиленнями), які через складність такого типу систем наближають їх до точок біфуркації. Це призводить до того, що системи стають нестійкими і для них настає невизначеність щодо подальшого стану: чи буде хаос, чи відбудеться перехід на новий рівень впорядкованості.

У сучасних умовах значно зросла роль гуманітарної складової людського становлення. Тому дедалі частіше суспільну капітальну оцінку отримують культурні характеристики людини як чинника модернізації - знання, інтелект, кваліфікація, навички, накопичений досвід, особисті якості, різносторонній розвиток, творчі здібності, комунікативність, особиста активність та відповідальність [2].

Сьогодні визначальним фактором модернізації регіональних господарських систем $\epsilon$ адаптація традиційних цінностей і мотивація економічних суб'єктів до інноваційних змін, генерація нових форм організаційно-економічних відносин.

«Індустрія 4.0» породжує нові технології, єдині цифрові системи, роботизовані виробництва, тотальну автоматизацію, відновлювальні енергоресурси. Принципи, на яких функціонує «Індустрія 4.0» орієнтуються на безпосередніх учасників цього процесу i передбачають:

- сумісність людини і машин через промисловий інтернет речей;

- прозорість взаємодії яка призводить до максимального накопичення інформації;

- технічну підтримку, яка, з одного боку, може повністю замінити людей машинами при виконанні важких операцій, а з іншого - комп'ютерні мережі дозволяють обробляти великі масиви даних, візуалізувати дані;

- можливість делегування управлінських рішень кіберсистемам;

- зміна бізнес-моделей та моделей поведінки;

- предиктивну аналітику;

- перехід до засад циркулярної економіки.

Перехід економік на нові принципи розвитку зовсім по-новому позиціонує роль людини у процесах модернізації. Так, за даними Всесвітнього економічного форуму [9] автоматизація виробничих процесів буде проходити настільки швидкими темпами, що найближчим часом це призведе до скорочення 85 млн робочих місць. Це стане серйозним викликом для ринку праці, а враховуючи спад ділової активності викликаної COVID-19 негативні ефекти будуть тільки посилюватись. Зокрема шанси на працевлаштування для мало- та середньокваліфікованого персоналу знижуються. Ринок праці формує попит на робочу силу з університетською освітою. Саме одним із викликів промислової революції $\epsilon$ необхідність постійного навчання та підвищення кваліфікації працівників.

Інтеграція та розвиток технологій, які є необхідною компонентою модернізаційних зрушень, вимагає трансформації знань, нових компетентностей працівника. Тобто людина стає носієм нових знань, здібностей, креативності та можливостей і таким чином відбувається нарощування людського потенціалу та його системна капіталізація.

Інформаційна економіка та роботизація виробництва спонукають до змін на ринках праці. Виникає попит на робочу силу нового типу, який визначається обсягом та структурою модернізації, рівнем продуктивності, кон'юнктурою на ринках капіталу, товарів та послуг. Орієнтація на сталий розвиток завдяки модернізації приводить до зростання попиту на робочі місця у сфері зеленої економіки, співпрацю зі штучним інтелектом, в управлінні соцмережами, біотехнологіях та генній інженерії, розробці індивідуального продукту. По- 
рядок денний майбутнього підкреслює важливість людської взаємодії в постмодерній економіці через функції у сфері маркетингу та продажів, створенні та наповненні інформаційного контенту, роботі з різними типами особистостей та з різним рівнем кваліфікації. Ці фактори суспільного життя також впливатимуть на пропозицію робочої сили.

Під час аналізу залучення елементів людського капіталу у процеси модернізації варто акцентувати увагу на такій його складовій, як капітал здоров'я - це складова, яка гарантує повноту життя, творчу діяльність та їхню ефективність.

Одним з елементів людського потенціалу, який буде затребуваний у модернізаційних змінах, є креативний капітал, оскільки аналітичне мислення, креативність та гнучкість у прийнятті рішень, здатність до самостійного навчання, особливо в епоху пандемії, стресостійкість, відповідальність стають затребуваними навичками.

Світ XXI ст. - це складене полісистемне утворення нового типу, яке розвивається в межах диджиталізації, цифрової революції в економіці, суспільстві, особистому житті.

Інформаційні технології стали органічною складовою сучасного світу, вони значною мірою визначають подальший розвиток людства. У цих умовах кардинальних змін вимагає і система навчання всіх рівнів, сьогодення не може функціонувати без засобів та не використовувати переваги, які надають комп’ютерні технології та засоби Інтернет.

Важливим фактором можливості модернізаційних зрушень стає постійне навчання, підвищення кваліфікації та перекваліфікація працівника. Тобто нарощування людського капіталу здійснюється як правило у сфері освіти, а не тільки у процесі безпосередньої праці. Завдяки цьому можна говорити про асоційований характер людського капіталу в інформаційному суспільстві. При цьому актуалізується роль інституцій освіти, які потребують системного вдосконалення, а також держави, яка повинна взяти на себе функції підтримки створення нових робочих місць майбутнього, запропонувати інструменти захисту працівників при зміні сфери використання робочої сили.

Вагома роль у процесах модернізації покладається на інтелектуальний капітал як елемент людського капіталу, що викликано вимогами до праці, а саме їі інтелектуалізації. Сучасна парадигма розвитку базується на таких чинниках, як збільшення частки розумових функцій у структурі трудової діяльності та використанні трудового потенціалу. Процеси модернізації відбуваються завдяки науковому поступу світу та не були б можливими без наукових досліджень та їх впровадження у виробництво. Можемо стверджувати, що постмодернізаційне суспільство - це суспільство, в якому переважає виробництво послуг, активно розвивається система навчання та розвитку компетентностей, наука посідає провідну роль у виробництві, а людський розвиток характеризується зростанням якості життя.

Пандемія викликана COVID-19 активізувала дистанційну форму роботи, яка постійно розширюється. Неможливість працювати в очному форматі призвела до використання віддалених форм роботи, які дозволили не втратити працівників та гарантувати їм економічне забезпечення. Водночас при такій формі роботи існують ризики поступового зниження продуктивності праці, втрати професійних навичок, зниження рівня соціальної активності, тому важливо розробляти та реалізовувати програми з адаптації працівника до роботи в нових умовах.

Якщо людський потенціал - це ресурс, сукупність творчих здібностей, знань та умінь, здоров'я індивідів, які можуть бути використані для відтворення особистості та суспільного розвитку, то, у свою чергу, людський капітал у широкому визначенні - це інтенсивний продуктивний фактор модернізації економіки, розвитку суспільства та сім’ї, що включає функціональні складові, зокрема, капітал освіти, інтелектуальний капітал, трудовий капітал тощо, що в поєднанні забезпечують ефективну модернізацію економіки й раціональне функціонування людського капіталу як продуктивного чинника розвитку (рис. 1). 
ПРОБЛЕМИ МЕНЕДЖМЕНТУ ТА РОЗВИТКУ ПРОДУКТИВНИХ СИЛ РЕГІОНУ

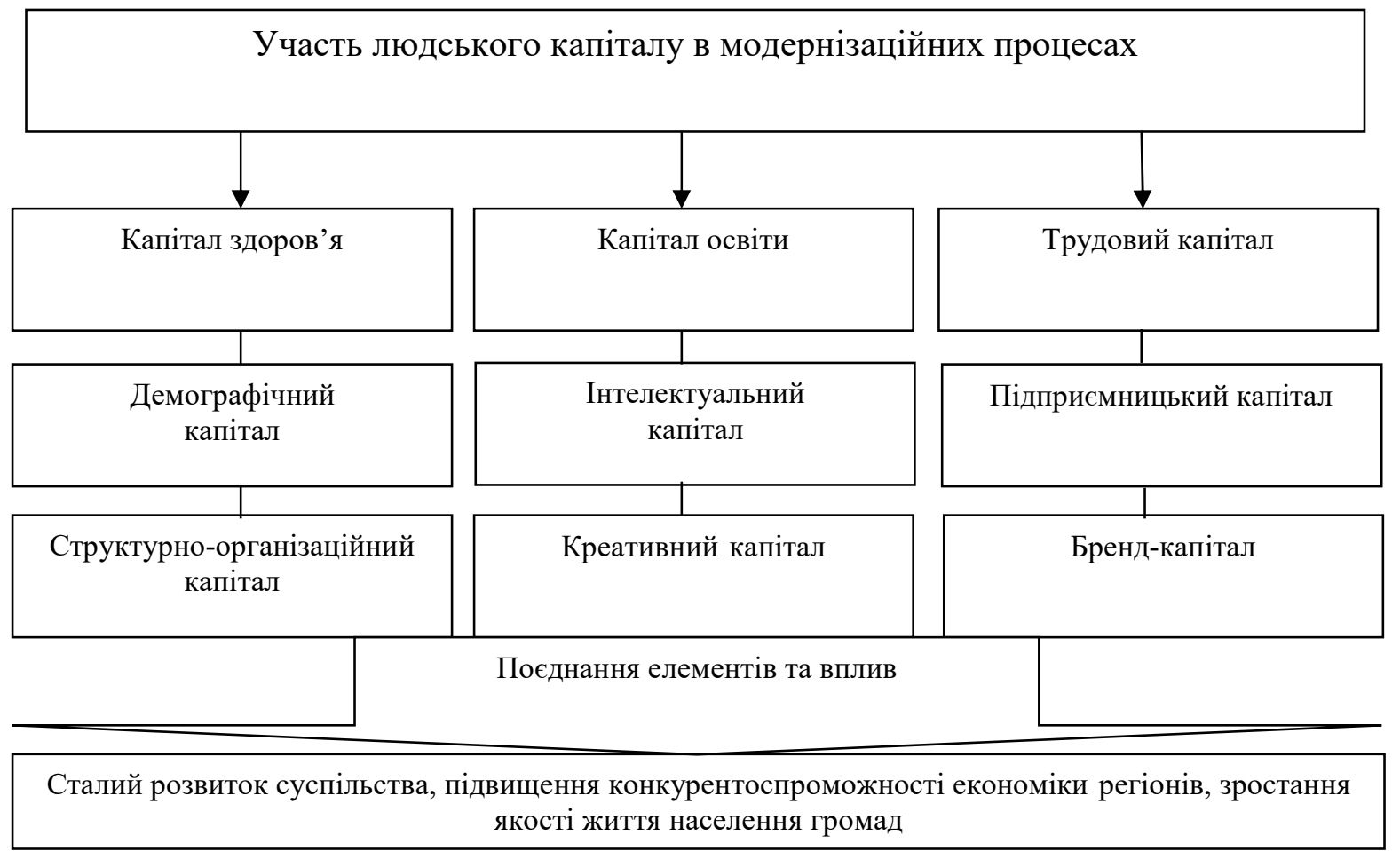

Рис. 1. Компоненти людського капіталу

Наведені елементи людського капіталу мають суб'єктний характер, тобто якісна характеристика людського капіталу полягає в тому, що його не можна відокремити від його власника (суб'єкта - людини). На відміну від інших видів капіталу, що виступають як капітал-об'єкт, людський капітал є капітал-суб'єкт. Завдяки капіталізації людського потенціалу, нарощуванню людського капіталу та його використанню, людина одночасно постає в багатовимірному просторі:

- як елемент процесів модернізації;

- кінцева мета модернізаційного поступу;

- результат економічного розвитку економічної системи;

- засіб подальшого розвитку;

Наукові підходи до розуміння людини як носія людського потенціалу та капіталу асоціюється 3 характеристиками сукупного працівника, що включає низку якостей особи, як то: антропологічні, освітні, інтелектуальні, культурні, особисті, колективні, суспільні. Тому процес модернізації не тільки визначає людський чинник як елемент цього процесу, а й слугує цілям розвитку людини, зростанню якості її життя, самоідентифікації, нарощуванню людського капіталу [4].

Стратегія модернізації регіональних економічних систем визначає низку базових пріоритетів серед яких вважаємо ключовим наступні:

- формування конкурентоспроможної економіки «Індустрії 4»;

- самоврядування громад, державний менеджмент;

- інвестування у людський капітал;

- цифровізація економіки;

- адаптація систем освіти до сучасних викликів;

- реформування мережі закладів охорони здоров'я;

- запровадження моделей розвитку з метою безперервної модернізації;

- визнання ключової ролі людини у процесах модернізаційних змін;

- модернізація регіональних економічних систем за напрямами цифровізації. 
Модернізаційний процес повинен бути стратегічно виваженим, відбуватись на засадах цілісності та планування, з використанням можливостей регіональної економіки задля створення нових цінностей та розробки нових видів продуктів та послуг. «ндустрія 4» висуває вимоги до нових компетентностей робочої сили, які можна сформувати шляхом навчання, розвитку sturt-up ідей.

Модернізація дає змогу регіональним економікам приймати інноваційні бізнесрішення завдяки залученню людського капіталу, використанню мережевих та автоматизованих даних, цифровим технологіям. Завдяки взаємозв'язкам між суб'єктами економіки, інноваціями та результатом їх впровадження, продуктивністю праці та якістю життя населення посилюється кумулятивний ефект модернізаційних зрушень.

Важливим фактором сталого розвитку та модернізаційних процесів є якісний людський капітал, який для інформаційної економіки визначено головним драйвером змін. Детермінанта сучасного розвитку передбачає накопичення якісного людського капіталу у відповідності з цілями та завданнями модернізації.

Висновки та пропозиції. Україна разом з усім світом вступає в епоху Індустрії 4, яка поряд із перевагами, зокрема: зростання продуктивності праці; оптимальний графік роботи для працівників; підвищення якості життя населення; зменшення впливу держави; перехід на засади циркулярної економіки, цифровізація тощо, має й свої недоліки: зростання безробіття через зміну кон'юнктури на ринках праці; зниження цін на типові послуги та товари; зростання нерівності як економічної так і соціальної; зростання залежність людини від техніки та інформації, тощо. Тому трансформації у світовій економічній системі, суспільні зрушення та виклики глобалізації, зростаюча міжнародна конкуренція, можливості економічного простору регіонів актуалізують питання модернізації регіональних господарських систем. Сформована економіка людського капіталу визначає його як першооснову у процесі модернізації та системних змін. Даний факт формулює задачу та мету розвитку суспільства в модернізаційний період, а саме випереджувальний розвиток людського капіталу та його складових. Одночасно модернізаційні зміни призведуть до формування людського капіталу нової якості, що підтверджує тезу про те, що людський капітал у модернізації одночасно виступає як вагомий чинник процесу і як об’єкт, на який спрямовано зміни.

\section{Список використаних джерел}

1. Бутко М. П., Мініна О. В. Теоретичні аспекти розвитку транзитного потенціалу регіонів України. Держава та регіони. Серія: Економіка та підприємництво. 2010. № 6. С. 84-92.

2. Быченко Ю. Г., Логинова Л. В. Модернизация общества и качество человеческого капитала. Известия Саратовского университета. Серия Социология. Политология. 2008. Вып. 2, т. 8. C. $47-54$.

3. Дергалюк Б. В. Управління структурною модернізацією регіональної економіки. Економіка та держава. 2020. № 4. С. 113-116. DOI: 10.32702/2306-6806.2020.4.113.

4. Дерій Ж. В. Роль людського потенціалу у постіндустріальному суспільстві. Науковий вісник Полтавського університету економіки і торгівлі. 2011. № 6(1). С. 310-316.

5. Лібанова Е. М. Модернізація економіки України в контексті соціальних викликів. Демографія та соиіальна економіка. Київ, 2011. № 1(15). С. 24-37.

6. Мініна О. В. Проблеми побудови стратегії підприємства в сучасних українських реаліях. Проблеми і перспективи економіки та управління : науковий журнал. 2019. № 3(19). С. 81-88.

7. Мініна О. В., Шадура-Никипорець Н. Т. Сутнісні ознаки регіонального економічного простору. Вісник Хмельницького національного університету. 2014. № 3, т. 2. С. 173-177.

8. Тульчинський Р. В. Децентралізація як чинник модернізації економіки регіональних суспільних систем в умовах становлення нового регіоналізму в Україні. Сучасні проблеми економіки і підприсмнищтво. Збірник наукових пращь. 2018. Вип. 21. С. 30-35.

9. The World Economic Forum. URL: https://www.weforum.org. 
ПРОБЛЕМИ МЕНЕДЖМЕНТУ ТА РОЗВИТКУ ПРОДУКТИВНИХ СИЛ РЕГІОНУ

\section{References}

1. Butko, M. P., Minina, O. V. (2010). Teoretychni aspekty rozvytku tranzytnoho potentsialu rehioniv Ukrainy [Theoretical aspects of the development of transit potential of the regions of Ukraine]. Derzhava ta rehiony. Seriia: Ekonomika ta pidpryiemnytstvo - State and regions. Series: Economics and Entrepreneurship, 6, pp. 84-92.

2. Bychenko, Yu. H., Lohynova, L. V. (2008). Modernyzatsyia obshchestva y kachestvo chelovecheskoho kapytala [Modernization of society and the quality of human capital]. Izvestiia Saratovskogo universiteta. Seriia Sotsiologiia. Politologiia - Proceedings of Saratov University. Sociology series. Political science, 2(8), pp. 47-54.

3. Derhaliuk, B. V. (2020). Upravlinnia strukturnoiu modernizatsiieiu rehionalnoi ekonomiky [Management of structural modernization of the regional economy]. Ekonomika ta derzhava Economy and state, 4, pp. 113-116. DOI: 10.32702/2306-6806.2020.4.113.

4. Derii, Zh. V. (2011). Rol liudskoho potentsialu u postindustrialnomu suspilstvi [The role of human potential in the post-industrial society]. Naukovyi visnyk Poltavskoho universytetu ekonomiky $i$ torhivli - Scientific Bulletin of Poltava University of Economics and Trade, 6(1), pp. 310-316.

5. Libanova, E. M. (2011). Modernizatsiia ekonomiky Ukrainy v konteksti sotsialnykh vyklykiv. [Modernization of Ukraine's economy in the context of social challenges]. Demohrafiia ta sotsialna ekonomika - Demography and social economy, 1(15), pp. 24-37.

6. Minina, O. V. (2019). Problemy pobudovy stratehii pidpryiemstva v suchasnykh ukrainskykh realiiakh [Problems of enterprise strategy construction in modern Ukrainian realities]. Problemy $i$ perspektyvy ekonomiky ta upravlinnia - Problems and prospects of economics and management, 3(19), pp. 81-88.

7. Minina, O. V., Shadura-Nykyporets, N. T. (2014). Sutnisni oznaky rehionalnoho ekonomichnoho prostoru [Essential features of the regional economic space]. Visnyk Khmelnytskoho natsionalnoho universytetu - Bulletin of Khmelnytsky National University, 3(2), pp. 173-177.

8. Tulchynskyi, R. V. (2018). Detsentralizatsiia yak chynnyk modernizatsii ekonomiky rehionalnykh suspilnykh system v umovakh stanovlennia novoho rehionalizmu v Ukraini. Suchasni problemy ekonomiky i pidpryiemnytstvo [Decentralization as a factor in modernizing the economy of regional social systems in the formation of a new regionalism in Ukraine. Modern problems of economy and entrepreneurship]. Zbirnyk naukovykh prats - Collection of scientific works, 21, pp. 30-35.

9. The World Economic Forum. https://www.weforum.org.

Дерій Жанна Володимирівна - доктор економічних наук, професор, завідувач кафедри теоретичної та прикладної економіки, Національний університет «Чернігівська політехніка» (вул. Шевченка, 95, м. Чернігів, 14035, Україна).

Дерей Жанна Владимировна - доктор экономических наук, профессор, заведующая кафедры теоретической и прикладной экономики, Национальный университет «Черниговская политехника» (ул. Шевченко,

95, г. Чернигов, 14035, Украина).

Derii Zhanna - Doctor of economy, Professor, Head of Department of Theoretical and Applied Economics, Chernihiv Polytechnic National University (95 Shevchenka St., 14035 Chernihiv, Ukraine).

E-mail: jannet $\mathrm{d} @$ ukr.net

ORCID: http://orcid.org/0000-0003-3695-7202

ResearcherID: F-3828-2014

Scopus Author ID: ID 57192007118

Дерій Ж. Місце людського капіталу в системі модернізаційних зрушень регіональної економіки. Проблеми і перспективи економіки та управління. 2020. № 3(23). С. 41-47. 